\title{
Continuous chemotrophic growth and respiration of Chromatiaceae species at low oxygen concentrations
}

\author{
Jörg Overmann* and Norbert Pfennig \\ Fakultäl für Bologic. Unıversitat Konstan7, Postfach 5560, W-7750 Konstanz, Federal Republic of Germany
}

Received December 20. 1991/Accepted February 15, 1992

\begin{abstract}
Endogenous and maximum respiration rates of nine purple sulfur bacterial strains were determined. Endogenous rates were below $10 \mathrm{nmol} \mathrm{O}_{2} \cdot(\mathrm{mg}$ protein $\cdot \min )^{-1}$ for sulfur-free cells and $15-35 \mathrm{nmol}$ $\mathrm{O}_{3} \cdot(\mathrm{mg} \text { protein } \cdot \mathrm{min})^{-1}$ for cells containing intracellular sulfur globules. With sullide as electron-donating substrate respiration rates were considerably higher than with thiosulfate. Maximum respiration rates of Thiocystis violacea 2711 and Thiorhodovibrio winogradskyi SSP1 (254.8 and $264.2 \mathrm{nmol} \mathrm{O}_{2} \cdot$ (mg protein $\cdot$ min) $)^{-1}$, respectively) are similar to those of aerobic bacteria. Biphasic respiration curves were obtained for sulfur-free cells of Thiocystis violacea 2711 and Chromatim vinosum 2811 . In Thiocystis violacea the rapid and incomplete oxidation of thiosulfate was five times faster than the oxidation of stored sulfur. A high affinity of the respiratory system for oxygen $\left(K_{m}=0.3 \quad 0.9 \mu \mathrm{M} \quad O_{2}, \quad V_{\max }=260 \mathrm{nmol}\right.$ $\mathrm{O}_{2} \cdot$ (mg protein $\cdot$ min $)^{-1}$ with sulfide as substrate, $K_{m}=0.6 \quad 2.4 \mu \mathrm{M} \quad \mathrm{O}_{2}, \quad V_{\max }=14 \quad 40 \mathrm{nmol} \quad \mathrm{O}_{2} \cdot(\mathrm{mg}$ protein $\cdot \mathrm{min})^{-1}$ with thiosulfate as substrate), for sulfide $\left(K_{m}=0.47 \mu \mathrm{M}, \quad V_{\max }=650 \mathrm{nmol} \mathrm{H}_{2} \mathrm{~S} \cdot(\mathrm{mg}\right.$ protein $x \min )^{-1}$, and for thiosulfate $\left(K_{m}=5-6 \mu \mathrm{M}, V_{\max }\right.$ $=24-72 \mathrm{nmol} \mathrm{S}_{2} \mathrm{O}_{3}^{2-} \cdot(\mathrm{mg} \text { protein } \cdot \min )^{-1}$ was obtained for different strains. Respiration of Thiocystis violacea was inhibited by very low concentrations of $\operatorname{NaCN}\left(K_{i}=1.7 \mu \mathrm{M}\right)$ while CO concentrations of up to $300 \mu \mathrm{M}$ were not inhibitory. The capacity for chemotrophic growth of six species was studied in continuous culture at oxygen concentrations of 11 to $67 \mu \mathrm{M}$. Thiocystis violacea 2711 , Amoebobacter rosetus 6611 , Thiocapsa roseopersicina 6311 and Thiorhodovibrio winogradskyi SSP1 were able to grow chemotrophically with thiosulfate/acetate or sulfide/acetate. Chromatium vinosum 2811 and Amoehobacter purpureus ML1 failed to grow under these conditions. During shift from phototrophic to chemotrophic conditions intracellular sulfur and carbohydrate accumulated transiently inside the
\end{abstract}

\footnotetext{
* Present address and address for correspondence: J. Overmann, Department of Microbiology, University of British Columbia, \# 300-6174 Unwersity Boulevard, Vancouver, B.C., Candda V6T $1 \mathrm{Z3}$
}

cells. During chemotrophic growth bacteriochlorophyll $a$ was below the detection limit.

Key words: Chromatiacede -- Continuous culture Respiration - Chemotrophic growth - Oxygen

The impact of molecular oxygen on the growth of purple sulfur bacteria (Chromatiaceae) has been investigated for a considerable period of time. Batch culture experiments of Pfennig (1971), Bogorov (1974), Gorlenko (1974), Kondratieva et al. (1976) and Kämpf and Pfennig $(1980,1986)$ revealed the capacity of Thiocapsa roseopersicina, Amoebobacter rosews, Thiocystis violacea, Clromatium vinosum, C. minus, C. violascens and C. gracile to grow in the dark by oxidizing reduced inorganic sulfur compounds with oxygen. In contrast, green sulfur bacteria did not grow chemotrophically (Kämpf and Pfennig 1980).

The growth experiments cited were performed either in batch or in fed-batch culture ( $\mathrm{K}$ ämpf and Pfennig 1986). Under these conditions chemotrophically growing cells still contained photosynthetic pigments (Gorlenko 1974, Kondratieva et al. 1976, Kämpf and Pfennig 1986). Furthermore, growth of some strains under dark conditions continued for a limited period of time but ceased after repeated transfer into fresh culture medium (Kämpf and Pfennig 1986). Therefore long-term continuous culture experiments are necessary to prove unequivocally the capacity for chemotrophic growth of Chromatiaceae with molecular oxygen.

Up to now, infinite chemotrophic growth in continuous culture and the absence of photosynthetic pigments was demonstrated exclusively for Thiocapsa roseopersicina strain Ml by de Wil and van Gemerden (1987, $1990 \mathrm{a}, \mathrm{b}$ ). The aim of the present study was to assess the capacity of six other Chromatiaceae species Cor continuous chemotrophic growth and to determine their respiratory activity under various conditions. 


\section{Materials and methods}

\section{Source of strains}

Amoebobacter purpureus strain ML1 and Thiorhodovibrio winogradskyi strain SSP1 (Overmann et al. 1991, 1992) were isolated from the chemocline and littoral sediment, respectively, of meromictic Mahoney Lake (British Columbia, Canada). All other strains were obtained from our culture collection at the University of Konstanz. For comparison, Thiocapsa roseopersicina strain M1 was kindly provided by Dr. H. van Gemerden, University of Groningen, The Netherlands.

\section{Respiration rates}

For initial measurements of respiration rates strains were grown in batch culture in completely filled $250 \mathrm{ml}$ screw cap bottles at $150 \mu \mathrm{mol} \mathrm{m} \mathrm{m}^{-2} \mathrm{~s}^{-1}$ of tungsten light (phototrophic conditions, growth medium see below) or under chemotrophic conditions in the dark on a rolary shaker in one liter Erlenmeyer flasks containing $200 \mathrm{ml}$ phosphate buffered growth medium (Kämpf and Pfennig 1980) under an atmosphere of $3 \% \mathrm{O}_{2}$ and $1 \% \mathrm{CO}_{2}$ in $\mathrm{N}_{2}$.

Respiration rates were determined in washed $(50 \mathrm{mM}$ potassium phosphate buffer, pH 7.4) cell suspensions employing a Clark type oxygen electrode (Model 53, Yellow Springs Instruments, Ohio, USA) in a thermostatted 10-ml cuvetle. The protein concentration of cell suspensions ranged between 100 and $300 \mu \mathrm{g} \cdot \mathrm{ml}{ }^{11}$. For calibration, aliquots of oxygen saturated buffer were injected into the assay and respiration rates calculated from the decrease of oxygen concentration with time. Substrates (sulfide and thiosulfate) were dissolved in degassed distilled water and stored under a nitrogen atmosphere.

\section{Continuous chemotrophic growth}

The growth medium contained per liter of distilled water: $\mathrm{KH}_{2} \mathrm{PO}_{4} \times \mathrm{H}_{2} \mathrm{O}, 0.25 \mathrm{~g} ; \mathrm{NH}_{4} \mathrm{Cl}, 0.34 \mathrm{~g} ; \mathrm{KCl}, 0.34 \mathrm{~g} ; \mathrm{MgSO}_{4}$ $\times 7 \mathrm{H}_{2} \mathrm{O}, 0.5 \mathrm{~g} ; \mathrm{CaCl}_{2} \cdot 2 \mathrm{H}_{2} \mathrm{O}, 0.25 \mathrm{~g} ; \mathrm{NaHCO}_{3}, 1.50 \mathrm{~g} ; \mathrm{Na}_{2} \mathrm{~S}_{2} \mathrm{O}_{3}$ $\times 5 \mathrm{H}_{2} \mathrm{O}, 0.99 \mathrm{~g}$ : Na-acelate, $0.33 \mathrm{~g}$; vilamin $\mathrm{B}_{12}, 0.02 \mathrm{mg} ;$ trace element solution SL 12 (Overmann et al. 1992), $1 \mathrm{ml}$. To media for strains M1, 5813, ML1, SSP1 requiring elevated salt concentrations, $\mathrm{NaCl}\left(20.0 \mathrm{~g} \cdot 1^{-1}\right)$ and $\mathrm{MgCl}_{2} \cdot 6 \mathrm{H}_{2} \mathrm{O}\left(2.8 \mathrm{~g} \cdot 1^{-1}\right)$ were added.

Experiments were performed in a modified laboratory scale fermentor Biostat $V$ (B. Braun, Melsungen, FRG). Incubation temperature was controlled with a Braun Thermomant thermostat. Dissolved oxygen was measured with an autoclavable polarographic oxygen electrode ( $\mathrm{Pt}-\mathrm{Ag} / \mathrm{AgCl}$ electrode IL, Ingoid, Urdorf, Switzerland). The combined pH electrode (No. 60216100, Metrohm $\Lambda \mathrm{G}$, Herisau, Switzerland) was inserted in the autoclaved fermentor vessel after $1 \mathrm{~min}$ of sterilization in boiling $0.5 \mathrm{M} \mathrm{HCl}$. To ensure anoxic conditions during anaerobic phototrophic growth, all connections except the pump hose (Tygon) were made of Isoversinic tube.

Defined gas mixtures of $\mathrm{N}_{2}, \mathrm{CO}_{2}$ and - under conditions enabling chemotrophic growth - pressurized air were adjusted with needie valves (Hoke, Cresskil, New Jersey, USA) and introduced directly into the culture. $\mathrm{A} \mathrm{pH}$ of $7.6 \pm 0.1$ (with thiosulfate as substrate) and $7.2 \pm 0.1$ (with sulfide) was maintained by adjusting the $\mathrm{CO}_{2}$ flow manually with a needle valve at the beginning of each experiment. Regulation of the oxygen partial pressure in the chemostat was accomplished by a proportional integral regulator (B. Braun) and a three way magnetic valve (Huba Control, Würenlos, Switzerland) which added alternatively pressurized air or $\mathrm{N}_{2}$ to the main gas strean. Thus, the gas flow through the culture was maintained at a constant rate. The range of oxygen concentrations applied was 11-67 $\mu \mathrm{M}$.

During phototrophic growth the culture was illuminated continuously from opposite sides with $3000 \mu \mathrm{mol} \mathrm{m} \mathrm{m}^{-2} \mathrm{~s}^{-1}$ of reflector tungsten lamps.
The oxygen tolerance of various Chromatiaccac strains increased in growth medium supplemented with acefate as organic carbon source (Kämpf and Pfennig 1980). In prcliminary experiments with acetate-free thiosulfate medium and in the absence of additional reducing compounds Chromatitan vinostum 2811 failed to grow even under anoxic conditions. Therefore the medium was routinely supplemented with sodium acetate. In contrast to purple nonsulfur bacteria, Chromatiaceae species proved unable to use acetate as electron-donating substrate for respiration (Gottert, personal communication).

For growth of Thiorhodovibrio winogradskyi strain SSP1 which does not oxidize thiosulfate, sterile $\mathrm{Na}_{2} \mathrm{~S}$-solution was pumped into the culture from an additional rescrvair (Beeftink and van Gemerden 1979) to yicld a final concentration of $1 \mathrm{mM}$. In these expcriments the second reservoir contained all other putrients in elevated concentrations according to the mixing ratio of both reservoir solutions.

\section{Analytical procedures}

Optical density of cell suspensions was measured at $650 \mathrm{~nm}$ in a Bausch and Lomb Spcctronic 70 photometer (Rochester, NJ, USA). Protcin was measured after Hartree (1972) and carbohydrate after Herbert et al. (1971). Dry cell mass was determined after filtration of cell suspensions on predried glass fiber filters GF 92 (Schleicher $\&$ Schuell, Dassel, FRG) and drying for $24 \mathrm{~h}$ at $105^{\circ} \mathrm{C}$.

Bacteriochlorophyll $a$ was extracted overnight at $4{ }^{\circ} \mathrm{C}$ with acetone $(99.5 \%)$; a specific extinction coefficient of $92.3 \mathrm{ml}$ $x(\mathrm{mg} \cdot \mathrm{cm})^{-1}$ (Steenbergen and Korthals 1982) was employed. The detection limit was $4 \mu \mathrm{g} \cdot 1^{-1}$.

Sulfide was measured colorimetrically by the methylene blue method (Cline 1969), thiosulfate and tetrathionate after Kelly et al. (1969) and zero valence sulfur (" $\mathrm{S}$ ") after Taylor et a1. (1989). For determination of sulfate, an ion chromatographic system (Sykam S 3110, Garching, FRG, equipped with a conductivity detector S 1000 and a Shimadzu, Kyoto, Japan, C-R3A integrator) was employed. Acetate was measured by gas chromatography (Schink and Pfennig 1982).

\section{Results and discussion}

\section{Specific rates and stoichiometry of respiration}

Maximum respiration rates at a non-limiting concentration of oxygen $(20 \mu \mathrm{M})$ and thiosulfate $(50 \mu \mathrm{M})$ or sulfide (20 $\mu \mathrm{M})$ (compare Fig. 2 and Table 3 ) did not differ significantly for phototrophically and chemotrophically grown cells. Even after identical incubation conditions, the mean standard deviation of maximum respiration rates between parallels was $50 \%(n=5-8)$. With sulfide, respiration rates were considerably higher than with thiosulfate (Table 1). Very low maximum respiration rates were found for Amoebobacter purpureus ML1 while Thiorhodovibrio winogradskyi SSP1 showed the highest rates. Endogenous respiration rates (i.e. in the absence of sulfide or thiosulfate) of cells free of intracellular sulfur globules generally were below $10 \mathrm{nmol}$ $\mathrm{O}_{2} \cdot(\mathrm{mg} \text { protein } \cdot \mathrm{min})^{-1}$. Cells containing sulfur globules exhibited endogenous rates of $15-35 \mathrm{nmol} \mathrm{O}_{2} \cdot(\mathrm{mg}$ protein $\cdot \min )^{-1}$ (Table 1).

As cells grown under anoxic conditions in the light respired reduced sulfur compounds at high specific rates the respiratory enzyme system must be constitutive in Chromatiaceae. In several Thiocapsa strains oxidation of thiosulfate and sulfite is mediated by the same enzyme 
Table 1. Specific respiration rates (RR) of various Chromatiaceae species"

\begin{tabular}{|c|c|c|c|c|c|}
\hline \multirow[t]{2}{*}{ Strain } & \multirow[t]{2}{*}{$\begin{array}{l}\text { Sub- } \\
\text { stratc }\end{array}$} & \multirow[t]{2}{*}{$\begin{array}{l}\operatorname{maxminulum} \mathrm{RR} \\
\mathrm{nmol} \mathrm{O}_{2} \cdot(\mathrm{mg} \text { protein } \cdot \min )^{-1}\end{array}$} & \multirow{2}{*}{$\begin{array}{l}\text { Stoichiometry } \\
\mu \mathrm{M} \text { Substrate: } \\
\mu \mathrm{MO}_{2}\end{array}$} & \multicolumn{2}{|c|}{$\begin{array}{l}\text { endogenous RR } \\
\text { nmol } \mathrm{O}_{2} \cdot(\mathrm{mg} \text { protein } \cdot \mathrm{min})^{-1}\end{array}$} \\
\hline & & & & $-\mathrm{S}^{0}$ & $+\mathbf{S}^{0}$ \\
\hline \multirow[t]{2}{*}{ Chromatiun vinosum D } & $\mathrm{S}_{2} \mathrm{O}_{3}^{2-}$ & 10.0 & $2: 1$ & 4.2 & 24.2 \\
\hline & $\mathrm{H}_{2} \mathrm{~S}$ & 177.3 & $3.3: 1$ & 8.4 & n.d. \\
\hline Chronatium vinosum 2811 & $\mathrm{~S}_{2} \mathrm{O}_{3}^{2-}$ & 16.7 & $1.7: 1$ & 2.0 & n.d. \\
\hline Thiocystis violacea 2711 & $\mathrm{H}_{2} \mathrm{~S}$ & 254.8 & n.d. & 13.0 & n.d. \\
\hline Thiocapsa roseopersicina 6311 & $\mathrm{~S}_{2} \mathrm{O}_{3}^{2-}$ & 69.9 & $1.9: 1$ & 5.9 & 29.3 \\
\hline Thiocapsa roseopersicina $\mathrm{Ml}$ & $\mathrm{S}_{2} \mathrm{O}_{3}^{2-}$ & 80.9 & $1.8: 1$ & 5.0 & 15.4 \\
\hline Amoebobacter roseus 6611 & $\mathrm{~S}_{2} \mathrm{O}_{3}^{2-}$ & 65.5 & $1.8: 1$ & 4.8 & 21.7 \\
\hline Amoebobacter pendens 5813 & $\mathrm{~S}_{2} \mathrm{O}_{3}^{2-}$ & 111.8 & $1.8: 1$ & 7.6 & 34.9 \\
\hline Amoebobucter purpureus ML1 & $\mathrm{H}_{2} \mathrm{~S}$ & 24.5 & $\mathrm{n}, \mathrm{d}$ & 9.8 & 5.7 \\
\hline
\end{tabular}

${ }^{a}$ Maximum respiration rates corrected for cndogenous rates (without exogenous substrate). Endogenous rates for cells without: $\left(-S^{0}\right)$ and with $\left(+S^{0}\right)$ microscopically visible sulfur globnles. As no significanl differences were detected between respiration rates of phototrophically or chemotrophically grown cells, the values were combined. Mean values of $5-8$ determinations. n.d. = not determined

system during phototrophic as well as during chemotrophic growth (Trüper 1984; Dahl and Trüper 1989). In phototrophic organisms the cytochrome $b_{1}$-complex is often involved in photosynthetic as well as respiratory electron transport (Scherer 1990). The high specific respiration rates of phototrophically grown cells have to be attributed to the presence of these components of the respiratory chann and a high activity of a terminal oxidase.

With $\mathrm{NaCN}$ an inhibitor constant of $K_{i}=1.7 \mu \mathrm{M}$ was determined for respiration of chemotrophically grown cells of Thiocystis violacea 2711. In contrast, no inhibition of respiration conld be detected with $\mathrm{CO}$ at a concentration of $300 \mu \mathrm{M}$.

Purple nonsulfur bacteria contain two different types of terminal oxidases. Electron transport occurs from ubiquinone via the cytochrome $b_{1}$-complex to cytochrome $c_{2}$ oxidase (cyt $b_{380}$ ) or directly from ubiquinone to the alternative oxidase (cyt $b_{250}$ ) (Venturoli et al. 1987; Richaud et al. 1986; Zannoni and Fuller 1988). While cytochrome $c_{2}$ oxidase is inhibited by very low cyanide concentrations (inhibitor constant $K_{i}=1-5 \mu \mathrm{M}$ ), the alternative oxidase requires much higher concentrations $\left(K_{i}=500 \mu \mathrm{M} \mathrm{KCN}\right)$. Only the alternative oxidase is inhibited by $\mathrm{CO}\left(K_{i}=770 \mu \mathrm{M}\right.$, o-type cytochrome $)$. According to the low inhibition constant of cyanide $\left(K_{i}=1 \cdots 7 \mu \mathrm{M}\right)$ and the insensitivity against $\mathrm{CO}$ in our experiments, Thiocysis violacea 2711 cells possess cytochrome $c_{2}$ oxidase as the terminal electron acceptor.

The two steps of thiosulfate oxidation with molecular oxygen can be described by:

$$
\begin{aligned}
& 2 \mathrm{~S}_{2} \mathrm{O}_{3}^{2-}+\mathrm{O}_{2} \rightarrow 2 \mathrm{~S}^{0}+2 \mathrm{SO}_{4}^{2-} \\
& \frac{2 \mathrm{~S}^{0}+2 \mathrm{H}_{2} \mathrm{O}+3 \mathrm{O}_{2} \rightarrow 2 \mathrm{SO}_{4}^{2-}+4 \mathrm{H}^{+}}{2 \mathrm{~S}_{2} \mathrm{O}_{3}^{2-}+4 \mathrm{O}_{2}+2 \mathrm{H}_{2} \mathrm{O} \rightarrow 4 \mathrm{SO}_{4}^{2-}+4 \mathrm{H}^{+}}
\end{aligned}
$$

where reaction (1) includes the activity of thiosulfate reductase, rhodanese and sulfite oxidase. Incompletc oxidation of thiosulfate in reaction (1) requires $2 \mathrm{~mol}$ of thiosulfate per $1 \mathrm{~mol}_{2}$, while during complete $0 x i d a t i o n$ (reaction 3) the ratio $\mathrm{S}_{2} \mathrm{O}_{3}^{2-}: \mathrm{O}_{2}$ is $1: 2$. The same holds true for oxidation of $\mathrm{H}_{2} \mathrm{~S}$. The respective ralio found in the experiments was $1.7: 1$ to $2.0: 1$ with thiosulfate and $2.5: 1$ to $3.3: 1$ with sulfide as electron-donating substrate (Table 1). This indicates incomplete oxidation of reduced sulfur substrates during the short-time incubations.

In some experiments phototrophically grown cells of Thiocystis violacea 2711 free of intracellular sulfur globules exhibited a biphasic respiration curve (Fig. 1). Following the addition of thiosulfate, the specific respiration rate was $44.8 \mathrm{nmol} \mathrm{O}_{2} \cdot(\mathrm{mg} \text { protein } \cdot \min )^{-1}$ and decreased abruptly to $169 \mathrm{nmol} \mathrm{O}_{2} \cdot(\mathrm{mg}$ protein $x \min )^{-1}$. The endogenous rate was very low in this case $\left(2.4 \mathrm{nmol} \mathrm{O}_{2} \cdot(\mathrm{mg} \text { protein } \cdot \min )^{-1}\right)$. Similarly, a biphasic curve of oxygen consumption was found for Chromatium vinosum 2811. The molar ratio between thiosulfate added and oxygen consumed was $1.8: 1$ at the end of the first phase of high respiration rate and

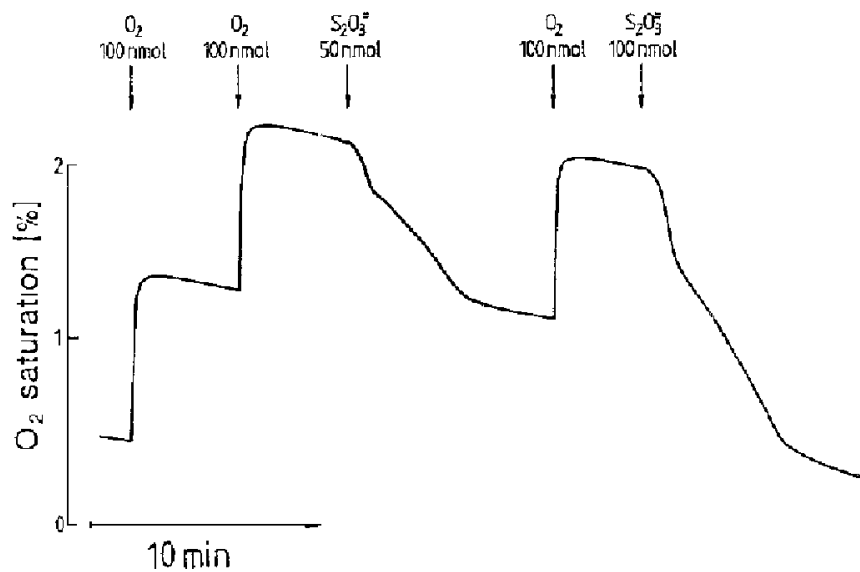

Fig. 1. Biphasic curve of oxygen depletion during respiration of Thiocystis nolacea 2711 clls. $\mathrm{T}=30^{\circ} \mathrm{C}$. Colls free of intracellular sulfur droplets, grown under pholotrophic conditions. Arrows indicate addition of oxygen and thiosulfate 
$0.6: 1$ at the end of the second phase. These ratios are in good agreement with the expected values for incomplete and complete oxidation.

If reaction (2) would not start before complete exhaustion of thiosulfate (reaction 1), the stoichiometry values at the end of reaction (1) should vary statistically around a mean value of $\mathrm{S}_{2} \mathrm{O}_{3}^{2-}: \mathrm{O}_{2}=2: 1$. However, the values measured $(1.7: 1$ to $2.0: 1)$ were systematically lower indicating oxidation of intracellular sulfur concomitant to thiosulfate oxidation. Similarly, a slow oxidation of intracellular sulfur in parallel with sulfide oxidation was demonstrated during phototrophic growth of Chromatium okenii (Trüper 1964).

Conversion of oxygen consumption rates during biphasic respiration of Thiocystis violacea yielded a rate of $55.8 \mathrm{nmol} \mathrm{S} \mathrm{O}_{3}^{2-} \cdot$ (mg protein $\left.\cdot \mathrm{min}\right)^{-1}$, Eq. (1) for the first phase and a rate of $11.3 \mathrm{nmol} \mathrm{S}^{0} \cdot(\mathrm{mg}$ protein $\times \min )^{-1}$ for the sceond phase. In this calculation the concomitant oxidation of the intracellular sulfur during reaction (1) was considered. The rate of incomplete oxidation of thiosulfate thus was 4.9 times higher than the oxidation rate of intracellular sulfur. For Chromatium vinosum D a very similar ratio of 4.6 was reported lor biphasic sulfate production with oxygen by Smith and Lascelles (1966).

Depending on the endogenous respiration rate the stoichiometry of thiosulfate oxidation in Thiocystis violacea 2711 varied considerably (Table 2 ). Biphasic respiration curves were not obtained al high endogenous rates. The low respiration rate during the second phase of hiphasic respiration (Fig. 1) is similar to the "endogenous" rates measured with Thiocystis violacea in other experiments and with various Chromatiaceae species (Table 1). Obviously the stoichiometries in Table 1 resulted from the fact that the very low respiration rates with intracellular sulfur are often indistinguishable from endogenous rates. Accordingly, cells apparently free of microscopically visible sulfur globules exhibited endogenous rates higher than $2.4 \mathrm{nmol} \mathrm{O}_{2} \cdot(\mathrm{mg} \text { protein } \cdot \min )^{-1}$ suggesting the presence of small amounts of stored sulfur inside the cells.

Determination of the $K_{m}$ values of respiration for thiosulfate, sulfide and oxygen revealed a high affinity for $\quad \mathrm{O}_{2} \quad\left(K_{m}=0.3 \quad 0.9 \mu \mathrm{M} \quad \mathrm{O}_{2}, \quad V_{\max }=260 \mathrm{nmol}\right.$ $\mathrm{O}_{2} \cdot$ (mg protein $\left.\cdot \mathrm{min}\right)^{-1}$ with sulfide as substrate, $K_{m}=0.62 .4 \mu \mathrm{M} \mathrm{O}_{2}, V_{\max }=14-40 \mathrm{nmol} \mathrm{O}_{2} \cdot$ (mg protein $\cdot \min )^{-1}$ with thiosulfate as substrate) (Fig. 2, Table 3) for all Chromatiaceae species studied. The affinity for sulfide of Thiorhodovibrio winogradskyi SSP1 was very
Table 2. Stoichiometry of thiosulfate oxidized to oxygen reduced at different endogenous respiration rates of Thiocystis violacea $2711^{\text {* }}$

\begin{tabular}{ll}
\hline $\begin{array}{l}\text { Endogenous respiration rate } \\
\text { nmol } \mathrm{O}_{2} \cdot(\mathrm{mg} \text { protcin } \cdot \text { min) }\end{array}$ & $\mu \mathrm{M} \mathrm{S} \mathrm{S}_{2} \mathrm{O}_{3}^{2-}: \mu \mathrm{M} \mathrm{O}_{2}$ \\
\hline 2.4 (p) & $0.6: 1$ \\
3.8 (c) & $0.7: 1$ \\
4.0 (p) & $1.2: 1$ \\
8.5 (c) & $2.4: 1$ \\
47.7 (p) & $2.0: 1$ \\
\hline
\end{tabular}

a At endogenous rates of $\geqq 4.0 \mathrm{nmo}] \mathrm{O}_{2} \cdot(\mathrm{mg} \text { protein } \cdot \min )^{-1}$ no buphasic respiration curve was ubserved. $\mathrm{p}=$ phototrophically, $\mathrm{c}=$ chemotrophicelly grown cells

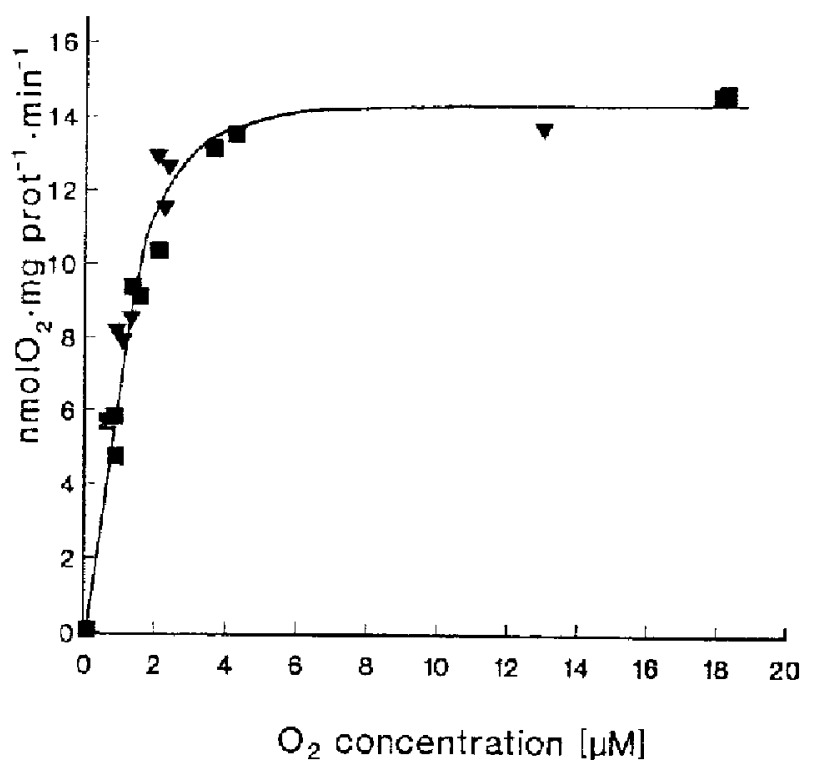

Fig. 2. Dependence of the specific respitation rate of Chromatitum vinosum 2811 on oxygen concentration. Rates were determined first at stepwise increased (rectangles), than at stepwise decreased (triangles) concentrations of oxygen

high $\left(K_{m}=0.47 \mu \mathrm{M}, V_{\max }=650 \mathrm{nmol} \mathrm{H}_{2} \mathrm{~S} \cdot(\mathrm{mg}\right.$ protein $\cdot \min )^{-1} \cdot K_{m}$ values of Chromatium vinasum 2811 and Thiocystis violacea 2711 for thiosulfate were between 5 and $6 \mu \mathrm{M}\left(V_{\max }=24-72 \mathrm{nmol} \mathrm{S}_{2} \mathrm{O}_{3}^{2-} \cdot(\mathrm{mg}\right.$ protein $\times \min )^{-1}$. Following the method of Eisenthal and Cornish-Bowden (1974), C. vinosum 2811 was grown phototrophically in a serics of chemostat experiments and a value of $K_{s}=7.4 \mu \mathrm{M}$ thiosulfate was calculated which is comparable to the $K_{m}$ of respiration.
Table 3. $K_{\mathrm{m}}$ values of $\mathrm{O}_{2}$ and electrondonating substrates for three different Chromatiaceac species

\begin{tabular}{llll}
\hline Strain & Growth conditions & $K_{m}\left(\mathrm{O}_{2}\right)[\mu \mathrm{M}]$ & $K_{m}\left(\mathrm{~S}_{2} \mathrm{O}_{3} / \mathrm{H}_{2} \mathrm{~S}\right)\lceil\mu \mathrm{M}]$ \\
\hline C. vinosum 2811 & phototrophic & $1.1 \pm 0.4$ & $4.8 \pm 2.5\left(\mathrm{~S}_{2} \mathrm{O}_{3}\right)$ \\
& chemotrophic & $1.2 \pm 0.4$ & n.d. \\
T. violacea 2711 & phototrophic & $2.4 \pm 0.4$ & $6.2 \pm 1.6\left(\mathrm{~S}_{2} \mathrm{O}_{3}\right)$ \\
& chemotrophic & $0.6 \pm 0.1$ & n.d. \\
T. winogradskyi & phototrophic & $0.9 \pm 0.1$ & $0.5 \pm 0.1\left(\mathrm{H}_{2} \mathrm{~S}\right)$ \\
SSP1 & chemotrophic & $0.3 \pm 0.1$ & n.d.
\end{tabular}

a Cells harvested 4 days after shift to chemotrophic conditions. $C$. vinosum did nol grow continuously under these conditions (see text). n.d. = not determined 
Continuous chemotrophic growth

With the exception of Chromatium vinosum D and Thiocapsa roseopersicina M1 which were investigated earlier (Kämpf and Pfennig 1986; de Wit and van Gemerden 1987, 1990a, b) and Amoebobacter pendens 5813, all species listed in Table 1 were examined for their capacity to grow chemotrophically with oxygen.
Pressurized air was added in small pulses to a phototrophically grown culture of Thiocystis violacea 2711 after reaching the steady state. The oxygen concentration in the culture medium was $11.1 \mu \mathrm{M}( \pm 0.6 \mu \mathrm{M})$ and the dilution rate $0.67 \mathrm{day}^{-1}$. Within ten days the Thiocystis cell suspension in the chemostat lost its purple-violet color completely. Concomitantly, bacteriochlorophyll a declined below the detection limit following the washout
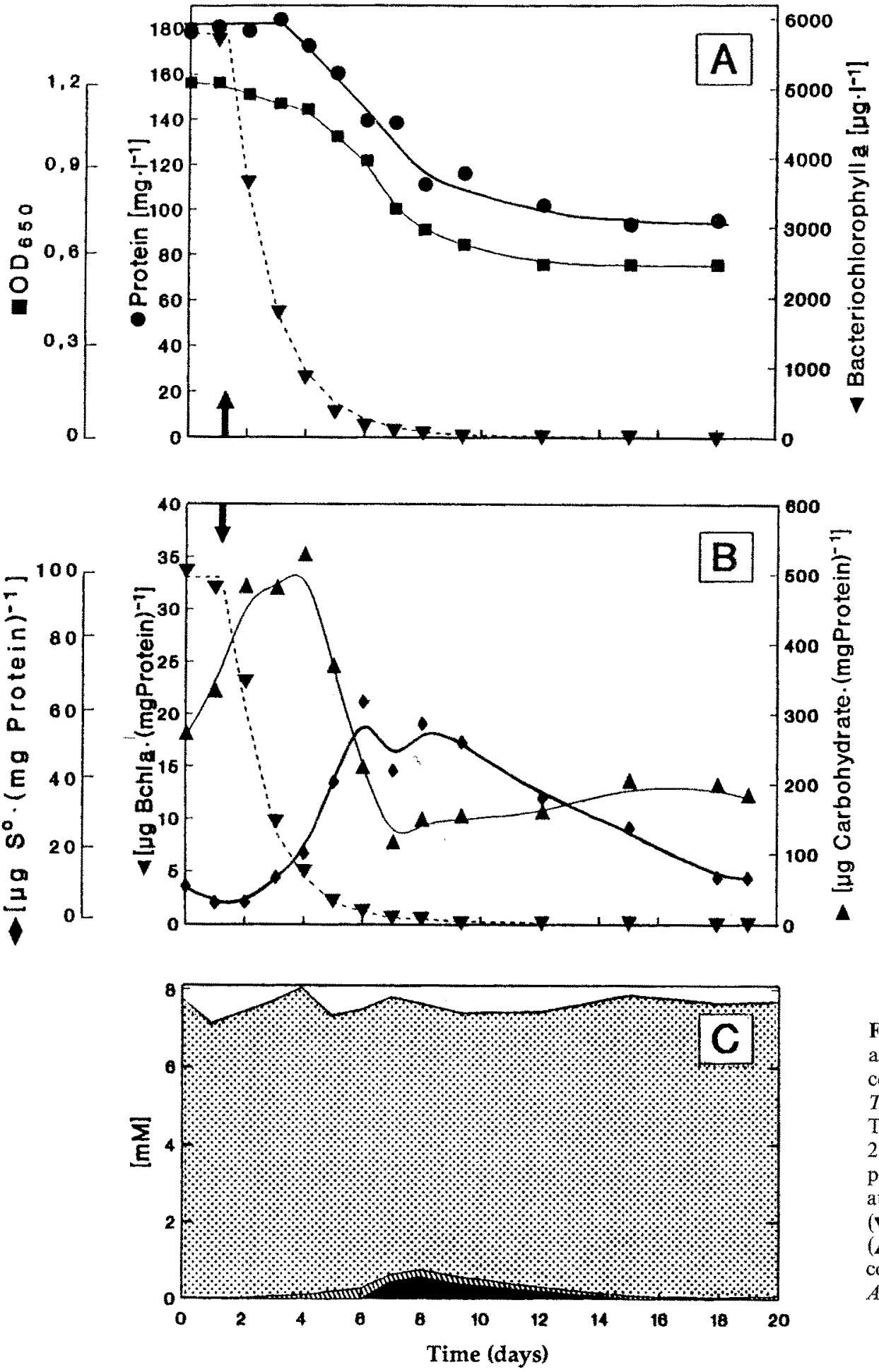

Fig. 3. Time course of biomass parameters at phototrophic and chemotrophic conditions in a continuous culture of Thiocystis violacea $2711 . \mathrm{D}=0.67 \mathrm{day}^{-1}$, $\mathrm{T}=25^{\circ} \mathrm{C}, \mathrm{pH}=7.6 \pm 0.1$, illumination $2 \times 3000 \mu \mathrm{mol} \mathrm{m} \mathrm{m}^{-2} \mathrm{~s}^{-1}$ (tungsten light), $\mathrm{pO}_{2}=1 \%(11 \mu \mathrm{M})$. (u) optical density at $650 \mathrm{~nm},(-)$ protein concentration, ( $\boldsymbol{\nabla})$ bacteriochlorophyll concentration, (A) intracellular carbohydrate concentration, $(\bullet)$ intracellular sulfur. Arrow indicates start of oxygen supply 
curve (Fig. 3) while the protein concentration decreased from a mean value of $181 \mathrm{mg} \cdot \mathrm{l}^{-1}$ during phototrophic growth to $93 \mathrm{mg} \cdot 1^{-1}$. The decrease of bacteriochlorophyll $a$ indicates repression of its synthesis by oxygen but no active breakdown. As revealed by electron microscopy, the decrease of bacteriochlorophyll a was paralleled by a decrease of the amount of pigment-bearing intracytoplasmic membrane vesicles.

Cells grew chemotrophically under light conditions as well as in the dark.

During phototrophic growth and assuming a mean biomass composition of $\left\langle\mathrm{C}_{4} \mathrm{H}_{8} \mathrm{O}_{2} \mathrm{~N}\right\rangle$ (Harder and van Dijken 1976), a biomass of $384 \mathrm{mg}$ (dry cell mass) $\cdot 1^{-1}$ can be expected from $4 \mathrm{mM} \mathrm{S} \mathrm{O}_{3}^{2-}$ and $4 \mathrm{mM}$ acetate according to the following equation

$$
\begin{aligned}
& 17 \mathrm{~S}_{2} \mathrm{O}_{3}^{2-}+17 \mathrm{CH}_{3} \mathrm{COO}^{-}+23 \mathrm{H}_{2} \mathrm{O}+30 \mathrm{CO}_{2} \\
& +16 \mathrm{NH}_{4}^{+} \rightarrow 16\left\langle\mathrm{C}_{4} \mathrm{H}_{8} \mathrm{O}_{2} \mathrm{~N}\right\rangle+34 \mathrm{SO}_{4}^{2-}+33 \mathrm{H}^{+} .
\end{aligned}
$$

A value of $359 \mathrm{mg}$ (dry cell mass) $\cdot 1^{-1}$, thus corresponding to $93 \%$ of the theoretical value was obtained expcrimentally.

After the shift to conditions enabling chemotrophic growth, a dry cell mass concentration of $186 \mathrm{mg} \cdot 1^{-1}$ was found. If $4 \mathrm{mM}$ acetate is converted completely into bacterial biomass according to

$16 \mathrm{CH}_{3} \mathrm{COO}^{-}+8 \mathrm{NH}_{4}^{+}+\mathrm{S}_{2} \mathrm{O}_{3}^{2-}+6 \mathrm{H}^{+}$

$\rightarrow 8\left\langle\mathrm{C}_{4} \mathrm{H}_{8} \mathrm{O}_{2} \mathrm{~N}\right\rangle+11 \mathrm{H}_{2} \mathrm{O}+2 \mathrm{SO}_{4}^{2-}$,

a dry cell mass concentration of $204 \mathrm{mg} \cdot 1^{-1}$ can be expected theoretically. The actual yield was $91 \%$ of this value. In the present experiment the cell yield was considerably lower than in chemotrophically growing batch cultures of Thiocystis violacea at similar substrate concentrations (Kämpf and Pfennig 1980). Of the total $4 \mathrm{mM}$ thiosullate added, only $0.25 \mathrm{mM}$ or $6.3 \%$ must have been oxidized during acetate assimilation. Thus it appears that most of the thiosulfate was respired for energy conservation by the Thiocystis cells in this experiment. From the dilution rate $\mathrm{D}\left(0.67 \mathrm{day}^{-1}\right)$, the protein concentration $c_{\text {protein }}\left(93 \mathrm{mg} \cdot \mathrm{l}^{-1}\right)$ and the thiosulfate concentration in the reservior $c_{\text {thir }}(4 \mathrm{mM}$, minus $0.25 \mathrm{mM}$ for reduction of acetate $=3.75 \mathrm{mM}$ ), a respiration rate $(\mathrm{RR})$ of $\mathrm{RR}=\mathrm{D} \cdot \mathrm{c}_{\text {fhii }} \cdot 2 / \mathrm{c}_{\text {protein }}=37.5 \mathrm{nmol} \quad \mathrm{O}_{2} \cdot(\mathrm{mg} \quad$ pro-
tein $\cdot \min )^{-1}$

was calculated which corresponds well with the maximum respiration rate measured in batch cultures (mean value : $33.5 \mathrm{nmol} \mathrm{O}_{2} \cdot(\mathrm{mg} \text { protein } \cdot \mathrm{min})^{-1}$, Table 1). Obviously, Thiocystis cells growing continuously under chemotrophic conditions respired at maximum rate.

During the shift to chemotrophic growth the intracellular sulfur content increased transiently (Fig. 3B) although thiosulfate was the growth-limiting substrate. Before and after this phase, the sulfur content of the culture was low $(15-40 \mu \mathrm{M})$ and thiosulfate was oxidized almost completely. The mean recovery of sulfur atoms derived from thiosulfate in this experiment was $95 \%$ (Fig. 3C). Similarly to Thiocystis violacea, intracellular sulfur concentrations in other species tested increased during the transition to chemotrophic growth. The same phenomenon was observed for Thiocapsa roseopersicina Ml (de Wit and van Gemerden 1987).

In chemotrophically grown cells of Thiocapsa roseopersicina, the activity of enzymes involved in thiosulfate oxidation (thiosulfate reductase, rhodanese, adenosin phosphosulfate reductase, ADP sulfurylase, ATP sulfurylase and sulfite oxidoreductase) is increased as compared to phototrophically grown cells (Dahl and Trüper 1989). As in all experiments intracellular sulfur accumulated transiently during the shift to chemotrophic growth, de novo synthesis and/or activation of the sulfur-oxidizing enzyme must be considerably slower compared to the other enzymes. Several findings in the literature support this conclusion. Redox calculations of de Wit and van Gemerden (1987) demonstrated that the oxidation rate of intracellular sulfur decreases during the shift of Thiocapsa roseopersicina M1 cells to chemotrophic growth. Hurlbert (1967) observed a decreased conversion of intracellular sulfur to sulfate by Chromatium vinosum in the presence of oxygen while the oxidation of the thiosulfate sulfane-sulfur to intracellular sulfur remained at a constant rate. The oxidation of sulfur appears to be the rate-limiting step during oxidation of polysulfides (Visscher et al. 1990). During chemolithoautotrophic growth, cells of Thiocapsa roseopersicina BBS strongly accumulated sulfur droplets which in this case even inhibited further growth (Kondratieva et al. 1975).

Amoebobacter roseus 6611 and Thiocapsa roseopersici$n a 6311$ were able to grow continuously under chemotrophic conditions (Figs. 4, 5). In order to shorten the time required per expcriment the dilution rate was increased. Thiocapsa roseopersicina reached a biomass yield (163 mg protein $\left.\cdot 1^{-1}\right)$ comparable to Thiocystis violacea $(181 \mathrm{mg}$ protein $\cdot 1^{-1}$ ). For Amoebobacter roseus the yield was considerably lower (Fig. 4). This may be attributed to the higher dilution rate of $\mathrm{D}=0.9 \mathrm{day}^{-1}$ which is closer to the maximum growth rate of chemotrophically growing cultures of Thiocapsa roseopersicina $\mathrm{Ml}$ (de Wit and van Gemerden 1987). At high dilution rates, substrates are not utilized completely and the growth yield is decreased (Herbert et al. 1956). Possibly the same holds true for the slightly decreased yield of Thiocapsa roseopersicina 6311 mentioned above $\left(\mathrm{D}=0.7 \mathrm{day}^{-1}\right.$ in this experiment).

Cultivation of Thiorhodovibrio winogradskyi SSP1 proved to be very difficult under conditions enabling chemotrophic growth. As this strain is unable to utilize thiosulfate, sulfide was added. For growth of strain SSP1 the sulfide concentration had to be decreased to $1 \mathrm{mM}$ and the oxygen partial pressure to $1 \%(11 \mu \mathrm{M})$. Nevertheless, the yield measured for phototrophically grown cells amounted to only $23 \%$ of the theoretical growth yield (24.3 versus $103.3 \mathrm{mg}$ protein $\cdot 1^{-1}$ ) indicating inhibition of cell growth of this strain. The dilution rate chosen in this experiment $\left(\mathrm{D}=0.6 \mathrm{day}^{-1}\right)$ was considerably lower than the maximum growth rate measured with sulfide and acetate as substrates in batch culture (2.0 day ${ }^{-1}$, Overmann et al. 1992). The protein concentration did not decrease concomitantly to the bacteriochlorophyll $a$ concentration at the end of the exper- 

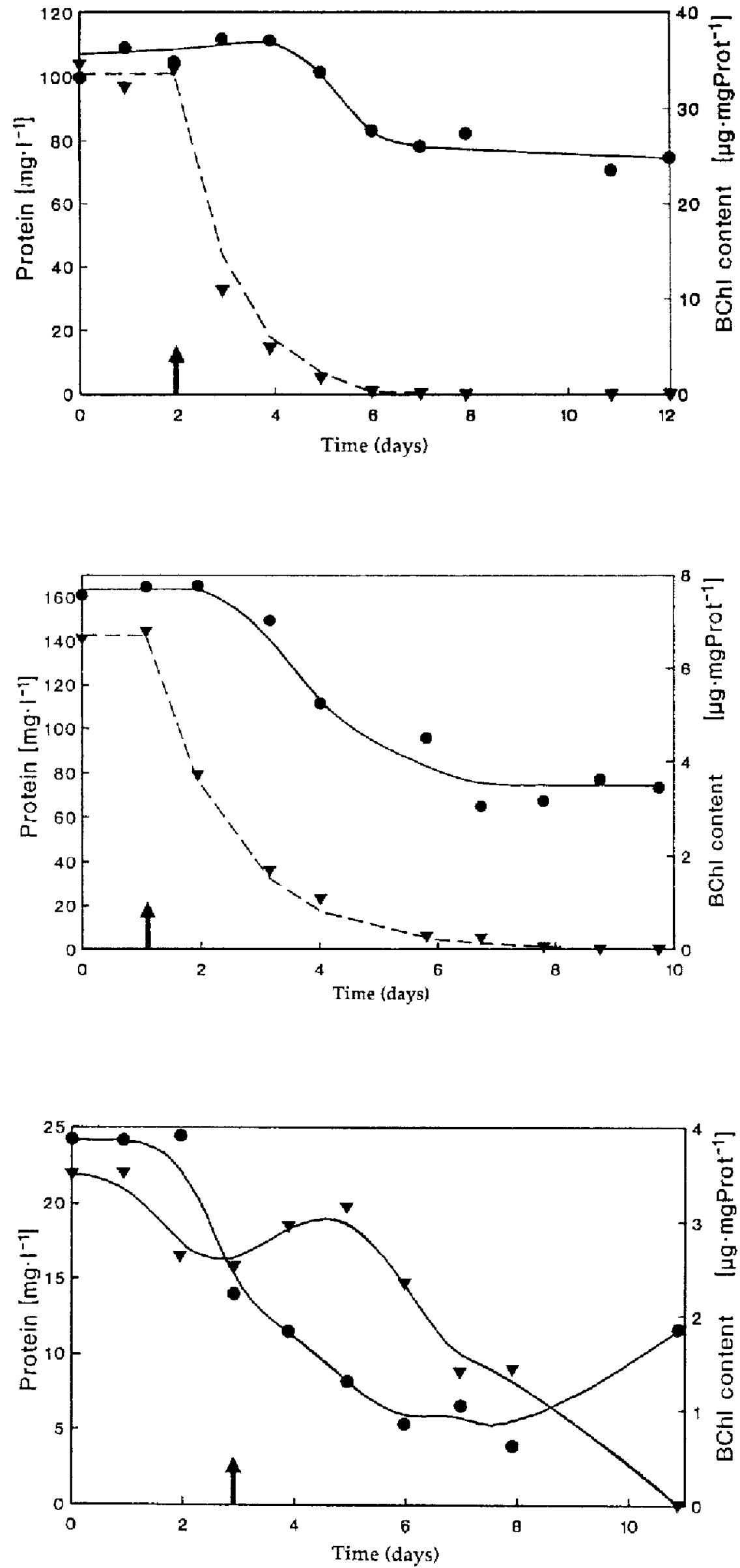

Fig. 4. Protein concentration (•) and spectic bacteriochforophyll content ( $\boldsymbol{\nabla}$ ) durng phototrophic and chemotrophic growth of a continuous culture of Amoebobacter roseus $6611 . \mathrm{D}=0.9 \mathrm{day}^{-1}, \mathrm{~T}=30^{\circ} \mathrm{C}, \mathrm{pO}_{2}=6 \%$. Arrow indicates start of oxygen supply

Fig. 5. Continuous culture of Thocapsa roseopersicina 6311 under phototrophic and chemotrophic conditions. $\mathrm{D}=0.7 \mathrm{day}^{-1}$, $\mathrm{T}=30^{\circ} \mathrm{C}, \mathrm{pO}_{2}=1 \%$. Symbols as in $\mathrm{F}_{1 \mathrm{~g} .4}$
Fig, 6. Contunous culture of Thiorhodoubro winogradskyi SSPI under phototrophic and chemotrophic conditions. $\mathrm{D}=0.6$ day $^{-1}$. $\mathrm{T}=30^{\circ} \mathrm{C} . \mathrm{pO}_{2}=1 \%$. Symbols as in Fig. 4 
iment (Fig. 6). Thiorhodovibrio winogradskyi SSP1 thus appears to be capable of chemotrophic growth.

The capacity for chemotrophic growth of Chromatium vinosum 2811 was studied in the same way at different oxygen concentrations and light intensities. After the switch to microoxic conditions $\left(\mathrm{pO}_{2}=1 \%\right)$ the intracellular bacteriochlorophyll content decreased and the carbohydrate content increased, but the sulfur concentration in the culture remained low. During the four days following the shift to microoxic conditions, the growth yield remained high at $91 \%$ of the theoretical value. Eventually cells formed clumps and adhered to the wall of the culture vessel. After six days, formation of large amounts of foam indicated considerably lysis of Chromatium cells. Similar results were obtained at low incubation light intensity (500 instead of $3000 \mu \mathrm{mol} \mathrm{m}^{-2} \mathrm{~s}^{-1}$ ) and at different oxygen concentrations $(11$ and $56 \mu \mathrm{M})$. Obviously Chromatium vinosum 2811 is unable to grow chemotrophically under these conditions.

Amoebobacter purpureus ML1 was washed out of the chemostat after shift from anoxic to microoxic conditions (D $=0.5 \mathrm{day}^{-1}$ ). This result corresponds well to the poor growth of this strain which was obtained in uniformly inoculated deep agar tubes incubated under oxic conditions in the dark (method of Kämpf and Pfennig 1980).

\section{Conclusions}

The present study shows that the capacity for continuous chemotrophic growth is not confined to the strain Thiocapsa roseopersicina $\mathrm{M} 1$ but is more widespread among the Chromatiaceae. A correlation exists between this capacily and high respiration rates.

The maximum respiration rates observed with the strains Thiocystis violacea 2711 and Thiorhodonibrio winogradsky SSP 1 are similar to those of aerobic bacteria (Cypionka and Meyer 1982). Chromatiaceae contain a terminal oxidase with a very high oxygen affinity $\left(K_{m}=\right.$ $0.34-2.4 \mu \mathrm{M}$ ). So far, only the very similar $K_{m}$ value for Thiocapsa roseopersicina $\mathrm{M} 10.64-1.42 \mu \mathrm{M}$; de Wit and van Gemerden 1987) has been reported. The oxygen affinity of Chromatiaccac is fully comparable to that of aerobic bacteria (Cypionka et a]. 1985). Chromatiaceae thus are able to take advantage of the very low oxygen concentrations which are present in boundary layers like the chemocline of meromictic lakes or at the top of sediment layers. Interestingly, most species which were able to grow continuously under microoxic conditions are often found in the redoxcline of laminated limnic and marine scdiment systems (van Gemerden et al. 1989; Pfennig 1989).

The diurnal variations of light intensity and sulfide concentration in natural habitats are considerably faster than the minimum time of live days required for the transition to chemotrophic growth in the present experiments. A loss of photosynthetic pigments and complete change of chemotrophic growth may rarely occur under natural conditions. More likely, the physiological flexibility as now demonstrated for several Chromatiaceae species provides a selective advantage during short period of simultaneous presence of reduced sulfur compounds and oxygen in the absence of light.

Acknowledgement. Wo are indebted to Dr. Claudia Wolff for the mcasurement of respiration rates of some Chromatiaceae strains. This work was partly supported by a grant of the Deutsche Forschungsgemeinschaft.

\section{References}

Beeltink HH, Gemerden H van (1979) Actual and potential rates of substrate oxidation and product formation in continuous cultures of Chromatitim vinosum. Arch Microbiol 121: 161-167

Bogorov LV (1974) Properties of Thiocapsa roseopersicina, strain BBS, isolated from a White Sea estuary. Mikrobiologiya 43: $326-332$

Clime JD (1969) Spectrophotometric determination of hydrogen sulfidc in natural watcrs. Limnol Occanogr 14: 454-458

Cypionka H, Meyer O (1982) Influence of carbon monoxide on growth and respiration of carboxydobacteria and other aerobic organisms. FEMS Micrabiol Lett 15: 209-214

Cypionka II, Reijnders WNM, Wielink JE van, Oltmann LF, Stouthamer AH (1985) Half reduction potentials and oxygen affini-

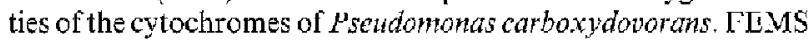
Microbiol Lett 27: 189-193

Dahl C, Triper HG (1989) Comparative enzymology of sulfite oxidation in Thiocapsa roseopersicina strains 6311, M1 and BBS under chemotrophic and phototrophic conditions. $Z$ Nalurforseh $44 \mathrm{c}: 617-622$

Eisenthal R, Cornush-Bowden A (1974) The direct linear plot. A new graphical procedure for estimating cuzyme kinetic parameters. Biochem J 139:715.720

Gemerden $H$ van, Tughan CS, Wit R de, Herbert RA (1989) Lam1nated microbial ecosystems on sheltered beaches in Scapa Flow, Orkney Islands. FEMS Microbiol Ecol 62: 87-102

Gorlenko VM (1974) Oxidation of thosulfate by Amoebohocter roseus in the dark under microacrophilic conditions. Mikrobiologiya 43: $729-731$

IIarder W, Dijken JP van (1976) Theoretical considerations on the relation between energy production and growth of methaneutilizing bacteria. In: Schlege $H G$, Gottschalk G, Pfennig N (eds) Symposium on microbial production and utilization of gases $\left(\mathrm{H}_{2}, \mathrm{CH}_{4}, \mathrm{CO}\right)$. E Goltze KG, Göttingen, FRG, p 403-418

Hartree FF (1972) Determination of protein: a modification of the LOWRY-method that gives a lincar photometric response. Anal B1ochem 48: 422-427

Herbert D, Elsworth R, Telling RC (1956) The continuous culture of bacteria, a theoretical and experimental study. J Gon Microbiol 14: 601-622

Herbert D, Phipps PJ, Strange RE (1971) Chemical analysis of microbial cells. In: Norris J, Ribbons DW (eds) Methods in microbiology, vol 5B. Academic Press. London, pp 209-344

Hurlbert RE (1967) Effect of oxygen on viability and substrate utilization in Chromatium. J Bacteriol 93: 1346-1352

Kämpf C. Pfennig N (1980) Capacity of Chromatiaceae for chemotrophic growth. Specific respuration rates of Thiocystis violaced and Chromatiam vinosem. Arch Microbiol 127: 125135

Kämp C C, PSinnig N (1986) Chemoautotrophic growth of Thiocystis violacea, Chromatium gracile and $C$. vinosum in the dark at various $\mathrm{O}_{2}$-concentrations. J Basic Microbiol 26: 517-531

Kelly DP, Chambers LA, Trudinger PA (1969) Cyanolysis and spectrophotometric estimation of trithionate in mixture with thiosulfate and tetrathionate. Anal Chem 41: 898-901

Kondratieva EN, Petushkova YuP, Zhukov VG (1975) Growth and oxidation of sulfur compounds by Thiocapsa roseopersicina in darkness. Mikrobiologiya 44: 389-394 
Kondratieva EN, Zhukov VG, Ivanovsky RN, Petushkova YuP, Monosov F.Z (1976) The capacity of photosynthetic sulfur bacterium Thiocapsa roseopersicma for chumosynthesis. Arch Microbiol 108: 287-292

Ovemann J, Beatty JT, Hall KJ, Pfening N, Northcote TG (1991) Characterization of a dense, purple sulfur bacterial layer in a meromictic salt lake. Limnol Oceanogr 36: 846-859

Overmann J, Fischer U, Pfennig N (1992) Thiorhodocibrio winogradskyi gen. nov, sp. nov, a new puxple sulfur bacterum from saline littoral sediments. Arch Microbiol (in press)

Pfennig N (1971) Dark growth of phototrophic bacteria under microaerophilic conditions. J Gen Microbiol 61: ii-iii

Pfennig N (1989) Ecology of phototrophic purple and green bacteria. In: Schlegel HG. Bowien B (eds) Autotrophe bacterja. Springer, Berlin Heidelberg New York, pp 97-116

Richaud P. Marrs BL, Vermeglio A (1986) Two modes of mteraction between photosynthetic and respiratory electron chains in whole cells of Rhodopseudomonas capsulata. Biochim Biophys Acta 850:256-263

Soherer S (1990) Do photosynthetic and respiratory electron transport chaitis share redox proteins? Trends Biochem Sci 15: $458 \quad 462$

Schınk B, Pfennig N (1982) Fermentation of trihydroxybenzencs by Pelobacter actdigalicici gen. nov. sp. nov. a nuw strictly anaerobic, non-sporeformung bacterium. Arch Microbiol 133: 195-201

Smith AJ, Lascelles J (1966) Thiosulphate metabolism and rbodanese in Chromatitm vinosum sp. strain D. J Gen Microbiol 42 : $357-370$

Steenbergen CLM. Korthals HJ (1982) Distribution of phototrophic microorganısms in the anaerobic and microaerophilic strata of Lake Vechten (The Notherlands). Pigment antlysis and role in primary production. Limnol Occanogr 27: 883-895
Taylor BF, Hood TA, Pope LA (1989) Assay of sulfur as triphenylphospbine sulfide by high performance liquid chromatography: application to studies of sulfur bioproduction and sulfur in marine scdiments. J Microbiol Methods: 221-231

Trüper HG (1964) Sulphur metabolism in Thiorhodaccae. II Stoichiometry relationshyp of $\mathrm{CO}_{2}$-fixation to oxidation of hydrogen sulphide and intraceliuar sulphur in Chromatium okenit. Antonie Van Leewwenhoek 30: 385 - 394

Trüper HG (1984) Phototrophic bacteria and their sulfur metabolism In: Müller $A$, Krebs $B$ (eds) Sulfur, its significance for chemistiy, for the geo-, bio-, and cosmosphere and techtology. Studies in inotganic chemistry, vol 5 Flsevicr, Amsterdam, PP $367-382$

Wit R de, Gemerden H van (1987) Chemolithotrophic growth of the phototrophic sulfur bacterium Thocapsa roseopersicina. FEMS Microbiol Lcol 45: 117-126

Wit R de, Gemerden H van (1990a) Growth of the photoautotrophic purple sultur bacterium Thiocapsa poveopersicina under oxic/anoxic regimens in the light. FEMS Microbiol Ecol 73: $69-76$

Wit R de, Gemerden H van (1990b) Growth and metabolism of the purple sulfur bacterium Thiocapsa roseopersicina under combined light/dark and oxic/anoxic regimens. Arch Microbiol 154: $459-464$

Venturoli G, Fenoll C. Zannoni D (1987) On the mechanism of respiratory and photosynthetic election transfer in Rhodospirillum rubrum. Biochim Biophys Acta 892: 172-184

Visscher PT, Vijburg JW, Gemerden H van (1990) Polysulfide utilization by Thioctapsaroseopersicina. Arch Microbiol 155: 75-81

Zanmoni D. Fuller RC (1988) Functional and spectral characterization of the respiratory chain of Chloroflexus aurantiacus grown in the dark under oxygen-saturated conditions. Arch Microbiol 150:368 373 